\title{
AEROSOLIZED MICROBES FROM ORGANIC RICH MATERIALS: CASE STUDY OF BAT GUANO FROM CAVES IN ROMANIA
}

\author{
Daniela R. Borda', Ruxandra M. Năstase-Bucur ${ }^{*}$, Marina Sînu², Raluca Uricariu², \\ AND JANEZ MuleC ${ }^{3}$
}

\begin{abstract}
Cave air, bat guano, and swabs of bat fur from caves with bat guano in Romania were analyzed by using RIDA ${ }^{\circledR}$ COUNT cultivation plates and standard selective media for Staphylococcus and Streptococcus. The samples of guano varied in concentration of cultivable chemoheterotrophic bacteria (max. $1.9 \times 10^{10} \mathrm{CFU} / \mathrm{g}$ ), coliforms (max. $2.2 \times 10^{8} \mathrm{CFU} / \mathrm{g}$ ), Escherichia coli (max. $1.0 \times 10^{8} \mathrm{CFU} / \mathrm{g}$ ), and yeasts and molds (max. $1.7 \times 10^{7} \mathrm{CFU} / \mathrm{g}$ ). The gravity-settling principle was applied to sample airborne microorganisms, and a new method was developed for evaluation of aerosolization potential. In cave air, the concentration of total bacteria was higher than yeast and molds. In addition to coliforms, enterobacteria, E. coli, and unidentified cultivable bacteria in the air samples, we also identified Chryseomonas luteola, Klebsiella pneumoniae, Micrococcus, Salmonella, Staphylococcus, and Streptococcus. In the experiment that provoked microbial aerosolization from guano, $3.35 \%$ of total cultivable fungi were aerosolized, up to $0.10 \%$ of bacteria, and $0.00 \%$ of E. coli. The concentration of Staphylococcus in the air exceeded counts of Streptococcus. The highest concentrations of airborne microorganisms were on the ground level. Using cultivation plates as a robust method we demonstrated that the relative proportion of microbial subgroups in the air remained constant in different seasons, with lower concentrations of airborne microbiota in the autumn. Caves as simplified natural systems demonstrated complex relationships between atmospheric parameters and microorganisms. Bats introduce into caves varying, but not negligible, concentrations of microbes on their fur. Caves with guano had relative high concentration of airborne microbes that may represent a biohazard for animals and humans.
\end{abstract}

\section{INTRODUCTION}

Air is an important habitat for metabolically active and reproducing microbes (Womack et al., 2010) and a vehicle for the transport of different microorganisms. When airborne, microorganisms can travel reasonable distances. For some microbes certain air conditions, such as desiccation, extreme temperature, UV radiation, or chemical and radioactive stressors, can be lethal.

Aerosolization, the production of an aerosol, results in a fine mist or spray containing minute particles that contain biological particles. There are different types of bioaerosol formation caused by wind, animals and humans, or splashing water (Mulec et al., 2012c). It occurs in natural and manmade environments. Human exposure to aerosols of organicrich materials generates a potential risk and can cause different types of infection. The health hazards of poor air quality can be associated with airborne microbes, and exposure to elevated concentrations of microorganisms can lead to numerous respiratory and dermatological infections, allergies, and other problems (Fabian et al., 2005).

The study of bioaerosols in controlled lab conditions provides valuable information, but trials under natural conditions provide a better insight into the fate of minute biological particles. Due to changeable atmospheric conditions and interrelated environmental stressors such as wind, UV, and humidity, some natural outdoor environments provide complex study conditions. A natural system that is low in environmental stressors and rich in organic material is karst caves harboring piles of bat guano. Caves are generally natural light-free environments connected with the outside by one or more entries, and with high relative air humidity, constant temperature, and low or negligible air movements (Simon, 2012; White and Culver, 2012). Poulson and Lavoie (2000) considered bat guano one of the most important energy inputs for caves in temperate climate zones. Guano is an important habitat, a source for microbial aerosolization, and a biohazard factor for humans and bats, e.g. Histoplasma capsulatum (Alteras, 1966; Jülg et al., 2008).

The objectives of this study were to define the relations between atmospheric parameters and airborne microorganisms that derive from in situ organic matter in caves.

\footnotetext{
* Corresponding author: ruxandra.nastase.bucur@academia-cj.ro

1 "Emil Racoviţă" Institute of Speleology, Department of Cluj-Napoca, Romanian Academy, Clinicilor St. 5, POBox 58RO-400006 Cluj-Napoca, Romania

${ }^{2}$ University of Agricultural Science and Veterinary Medicine, Faculty of Veterinary Medicine, Calea Mănăştur 3-5, RO-400372 Cluj-Napoca, Romania

${ }^{3}$ Karst Research Institute, Research Centre of the Slovenian Academy of Sciences and Arts, Titov trg 2, SI-6230 Postojna, Slovenia
} 
D.R. Borda, R.M. Năstase-Bucur, M. Spînu, R. Uricariu, and J. Mulec

Table 1. Caves studied, with abbreviations used in the figures. The distance from the cave entrance to the most remote bioaerosol sampling site is included. Lithology after Bandrabur and Radu, 1994, Bleahu et al., 1976, and Todoran and Onac 1987; biogeographical regions after ANPM, 2013.

\begin{tabular}{llclc}
\hline Cave & $\begin{array}{c}\text { Biogeographical } \\
\text { Region }\end{array}$ & $\begin{array}{c}\text { Entrance } \\
\text { a.s.1. }(\mathrm{m})\end{array}$ & \multicolumn{1}{c}{ Lithology } & $\begin{array}{c}\text { Studied Distance / } \\
\text { Length of Cave (m) }\end{array}$ \\
\hline Adam Cave, AC & Continental & 295 & Jurassic / Cretaceous limestone & $25 / 169$ \\
Cheile Turzii Cave, CT & Alpine & 552 & Jurassic limestone & $36 / 120$ \\
Fuşteica Cave, FC & Continental & 200 & Jurassic / Cretaceous limestone & $47 / 1270$ \\
Gura Dobrogei Cave, GD & Steppe & 46 & Jurassic limestone & $125 / 500$ \\
Meziad Cave, MC & Alpine & 440 & Triassic limestone & $375 / 4750$ \\
Răstoci Cave, RC & Continental & 319 & Eocene / Oligocene limestone & $87 / 507$ \\
Topolniţa Cave, TC & Continental & 434 & Jurassic / Cretaceous limestone & $320 / 20500$ \\
\hline
\end{tabular}

Caves in Romania with bat guano were studied to observe seasonal and air-stratification effects on concentration of bioaerosols, as well as to estimate the level of aerosolized microbes from guano and the role of bats as vectors for microbial transmission. To estimate the percentage of aerosolization, a new method to induce aerosolization was developed and tested in caves. Results from the study are useful for comparison with other organic-rich environments that contain biohazard microbes, such as farms, landfills, and wastewater or compost treatment plants.

\section{Materials And Methods}

\section{Study Sites}

Seven caves that are rich in guano deposits and populated by bats in three biogeographic and climate regions in Romania were selected: Avenul lui Adam (Adam Cave), Peştera Cetăţeaua Mare din Cheile Turzii (Cetă- ţeaua Mare Cave from Gorges of Turda, referred to in the text and tables as Cheile Turzii Cave), Peştera Fuşteica (Fuşteica Cave), Pestera Liliecilor de la Gura Dobrogei (Bat Cave from Gura Dobrogei, referred to as Gura Dobrogei Cave), Peştera Meziad (Meziad Cave), Peştera de la Răstoci/ Peştera Măgurici (Răstoci Cave), and Peştera Topolnița (Topolniţa Cave) (Table 1). Apart from Cheile Turzii Cave, which contains a maternity roost, the other caves host bats all year round, including maternity and hibernation colonies. The most prevalent bat species and number of species in each cave are presented in Table 2.

Adam Cave is located in Băile Herculane area in the Domogled-Cerna Valley National Park, which has 700 to $750 \mathrm{~mm}$ of annual precipitation (Munteanu, 2011). The cave entrance is vertical, starting with an $11 \mathrm{~m}$ shaft. Temperature is constant year round, with an average of $27{ }^{\circ} \mathrm{C}$ that is attributed to intermittent steam vapors; water

Table 2. Bats in studied caves; data from Borda, 2002a, b; Borda et al., 2004; Burghele-Bălăcescu and Avram, 1966; Carbonnel et al., 1996; Coroiu et al., 2007; Pocora and Pocora, 2011.

\begin{tabular}{|c|c|c|c|c|}
\hline Cave & Presence & $\begin{array}{l}\text { Number of } \\
\text { Individuals }\end{array}$ & $\begin{array}{l}\text { Number of } \\
\text { Bat Species }\end{array}$ & Main Guano Contributors \\
\hline Adam Cave & All year & 5000 & 8 & $\begin{array}{l}\text { Miniopterus schreibersii } \\
\text { Myotis capacinii } \\
\text { Myotis myotis } \\
\text { Rhinolophus euryale }\end{array}$ \\
\hline Cheile Turzii Cave & Summer & 1500 & 3 & $\begin{array}{l}\text { Miniopterus schreibersii } \\
\text { Myotis myotis / M. oxygnathus }\end{array}$ \\
\hline Fuşteica Cave & All year & 1500 & 7 & $\begin{array}{l}\text { Miniopterus schreibersii } \\
\text { Myotis capacinii } \\
\text { Myotis myotis / M. oxygnathus }\end{array}$ \\
\hline Gura Dobrogei Cave & All year & 300 & 10 & $\begin{array}{l}\text { Miniopterus schreibersii } \\
\text { Myotis daubentonii } \\
\text { Myotis myotis / M. oxygnathus }\end{array}$ \\
\hline Meziad Cave & All year & $5000-7000$ & 10 & $\begin{array}{l}\text { Miniopterus schreibersii } \\
\text { Myotis myotis / M. oxygnathus }\end{array}$ \\
\hline Răstoci Cave & All year & 200 & 5 & Myotis myotis / M. oxygnathus \\
\hline Topolniţa Cave & All year & 1500 & 10 & $\begin{array}{l}\text { Miniopterus schreibersii } \\
\text { Myotis myotis / M. oxygnathus }\end{array}$ \\
\hline
\end{tabular}


temperature is around $42{ }^{\circ} \mathrm{C}$ and bursts of vapor at 44.5 to $53{ }^{\circ} \mathrm{C}$ (Povară et al., 1972). Because of these particularities, the Adam Cave is unique in Romania, being a tropical-type cave, distinct from all other caves from Romania. Due to the intermittent steam emissions, air mixing is caused by the ascending warm and descending colder air. The air circulation is more obvious in the winter, when temperature differences between cave and external air are more pronounced. The warm air accumulating in the cave becomes a perfect shelter for maternity colonies of bats. The largest guano heap in the Guano Gallery is up to $2.5 \mathrm{~m}$ high (Carbonnel et al., 1996).

Cheile Turzii Cave is a small cave located on the right slope of Haşdate Valley in the Trascău Mountains where the average annual precipitation is around $600 \mathrm{~mm}$ (Beldean, 2005). In the past, the cave offered shelter for the local people against invasions. The entrance still contains part of a fortification wall that partially obstructs normal air ventilation.

Fuşteica Cave is located in the Vîlcan Mountains where the annual average precipitation is approximately $800 \mathrm{~mm}$ (Costache, 2011). This is an active cave with large guano deposits that are partially flushed away by an intermittent subterranean stream that drains to the Isvarna River (Burghele-Bălăcescu and Avram, 1966). Both maternity and hibernation bat colonies are sheltered in the cave.

Gura Dobrogei Cave is located in Dobrogea in southeastern Romania. Annual precipitation in the region is 350 to $450 \mathrm{~mm}$ (Lungu, 2008). In the Fossils Gallery there are large quantities of old and fresh deposits of guano.

Meziad Cave is partly a tourist cave and is located in the Pădurea Craiului Mountains, part of the Apuseni Mountains. The annual average of precipitation in the area is $720 \mathrm{~mm}$ (Moza, 2008). The cave is a big subterranean cavity developed on three levels, the main gallery, the first floor, and the second floor. Meziad Cave was included in the study because of big maternity and mating colonies of bats and important fresh guano deposits. During our research activities there has been no electrification and no construction of new trails; this resulted in minimal human visits and preservation of the bat population. The cave has a front gate embedded in an artificial stone wall three meters high.

Răstoci Cave is one of the main caves of the Someşan Plateau of Transylvania, and it is the only cave in that area that shelters a considerable number of bats. The annual average precipitation in the Someşan area for the last hundred years is $635 \mathrm{~mm}$ (Sorocovschi and Vodă, 2009).

Topolniţa Cave is a large cave located in the Mehedinţi Mountains where precipitation is between 900 and $1,000 \mathrm{~mm}$ per year (Robu, 2009). The gallery network of the cave is developed on four levels, two dry (one lower and one upper), one semi-active, and the lowest one active. We investigated only the upper inactive part of the cave, where $H$. capsulatum was detected for the first time in Europe (Alteras, 1966). A gate installed in 1960s restricted the access of bats in this part of the cave and probably induced changes in atmospheric conditions. In 1996 two new openings for bats were cut in the wall, which allowed for re-colonization by bats.

\section{Microbiological Media and Reading Results}

Due to the proven versatility of RIDA ${ }^{\circledR}$ COUNT cultivation plates in caves (Mulec et al., 2012a, b) and in organic-rich environments (Oarga et al., 2012), the following varieties of this product were used: for total bacterial counts (RIDA ${ }^{\circledR}$ COUNT Total Aerobic Count), for Escherichia coli and coliforms (RIDA ${ }^{\circledR}$ COUNT E. colil Coliform), for enterobacteria (RIDA ${ }^{\circledR}$ COUNT Enterobacteriaceae), and for yeast and molds (RIDA ${ }^{\circledR}$ COUNT Yeast\&Mold Rapid). After 24 and 48 hours of cultivation at $37{ }^{\circ} \mathrm{C}$, readings of bacterial growth were scored. For yeasts and molds, readings were taken after 48 and 72 hours of cultivation at the temperature of $25^{\circ} \mathrm{C}$. The counts of bacteria after 48 and for fungi after 72 hours were considered for statistical analyses. Prolonged incubation for 24 hours gives a more realistic view of the microbial communities, as some cave microbes have demonstrated slow growth on RIDA ${ }^{\circledR}$ COUNT media (Mulec et al., 2012a). Isolates that exhibited B-D-glucuronidase and B-Dgalactosidase biochemical activities on RIDA ${ }^{\circledR} \mathrm{COUNT} E$. coli/Coliform plates were considered indicative of $E$. coli (R-Biopharm AG, Germany).

To supplement RIDA ${ }^{\circledR}$ COUNT readings with additional indicators of potential pathogenic microbes, we used the standard selective media for Streptococcus (Azide bloodagar medium; Holmes and Lermit, 1955) and Staphylococcus (Mannitol salt agar medium; Chapman, 1945). Open Petri plates with these media were placed parallel to RIDA $^{\circledR}$ COUNT plates in Meziad Cave and Cheile Turzii Cave. The plates were incubated at $37^{\circ} \mathrm{C}$, and colonies were counted after 24 and 48 hours. This approach is frequently used in Romania to quantify airborne microbiota in organic-rich environments such as domestic farms (Drăghici et al., 2002), zoos (Borda et al., 2012), and caves with bat guano (Borda et al., 2004; 2009; Borda and Borda, 2004).

For subsequent identification of bacterial isolates from Adam Cave and Topolnița Cave, the morphologically distinct colonies developed on Total Aerobic RIDA ${ }^{\circledR}$ COUNT were plated on glucose nutrient agar (Oxoid, UK) and MacConkey agar (Sigma-Aldrich). After Gram staining, API ${ }^{\circledR}$ strips (Biomérieux, France) were used to identify isolates, API20E for enteric bacteria, API20NE for non-enteric Gram-negative bacteria, and APIStaph for identification of staphylococci and micrococci. The results were interpreted using APIweb software.

\section{Sampling Procedure and Atmospheric Parameters}

Four different types of samples were analyzed: bat guano, cave air, cave air inoculated with guano by our in situ aerosolization procedure, and swabs of bats' fur. For 
air samples, results are reported as colony-forming units (CFU) per surface in a definite period of sampling, e.g., $\mathrm{CFU} / 20 \mathrm{~cm}^{2} / 20 \mathrm{~min}$, for guano as CFU per gram (w/v), and for swabs as CFU per surface, e.g. CFU/20 $\mathrm{cm}^{2}$.

Fresh guano and guano accumulated in caves in previous years were included in the study. For microbiological analysis, guano heaps were aseptically sampled with a spoon in a range from 0 to $5 \mathrm{~cm}$ depth. After sampling, characteristics of guano heaps were measured: volume, surface area, and $\mathrm{pH}$. $\mathrm{pH}$ was measured at the site using $\mathrm{pH}$ indicator strips (EMD Chemicals, Germany) after a sample of guano was homogenized with an equal part of sterile deionised water. Samples for microbiological analyses were transported in a cool box to the lab as soon as possible. After establishing the weight of a guano samples, generally around $2 \mathrm{~g}, 15 \mathrm{~mL}$ of sterile physiological saline was added to the samples and rigorously vortexed. This mixture was serially diluted up to $10^{-8}$. One milliliter of these serial dilutions was applied onto RIDA ${ }^{\circledR} \mathrm{COUNT}$ test plates. Microbial counts were expressed as colony-formingunits per gram.

To sample airborne microorganisms the gravity-settling method was adopted. Open plates with media were exposed to the cave atmosphere for 20 minutes and, after cultivation in laboratory conditions, microbial counts were expressed as CFU per surface unit (Borda et al., 2004; Mulec, 2008; Mulec et al., 2012a, b). In caves, bioaerosol was sampled on the ground floor at different distances from the cave entrance and guano heaps. Besides the horizontal gradient sampling, a vertical gradient of bioaerosols was also sampled by using a $1.5-\mathrm{m}$ standing rack. To diminish the influence of researchers' presence upon the air quality, sampling was performed consecutively; the first sample was taken at the cave entrance, and the next ones later at previously selected sites, up to the last sampling sites at a guano heap in the cave. If cave morphology at a particular site allowed, sampling was performed in duplicate or triplicate, and the average CFU value was used in subsequent analyses. After sampling was finished, the distances from the cave entrance and guano heap for each individual sampling site was measured. In some caves (Adam Cave, Fuşteica Cave, Gura Dobrogei Cave, Răstoci Cave, Topolniţa Cave) aerosols were sampled once per year, while in Cheile Turzii Cave and Meziad Cave we also sampled in different periods of the year in order to observe seasonal variability. The summer investigations in these two caves took place once the fresh guano was deposited.

In selected caves (Cheile Turzii Cave, Gura Dobrogei Cave, and Meziad Cave) we performed artificially induced aerosolization to estimate the maximum numbers of cultivable microorganisms from aerosols. A spoon of guano was aseptically transferred to a sterile beaker (diameter $7 \mathrm{~cm}$, height $9 \mathrm{~cm}$, with total volume of 0.346 liter). To provoke in situ aerosolization of microbes in guano, the beaker with guano was temporary sealed with a plastic bag and manually shaken for ten seconds. Big particles of guano were shaken off and removed from the beaker, and the beaker was placed with the opening over the RIDA ${ }^{\circledR}$ COUNT media for 20 minutes, so the airborne microbes could settle (Fig. 1). The inoculated RIDA ${ }^{\circledR}$ COUNT media was later transferred in the laboratory and incubated as previously described.

During natural aerosol sampling we measured atmospheric parameters, temperature, relative humidity ( $\mathrm{RH})$, and air pressure with a Kestrel 4500 Pocket Weather Tracker. The carbon dioxide concentration in the atmosphere was measured with a MI70 Vaisala $\mathrm{CO}_{2}$ meter.

Swabs of bat coats were sampled to get an idea of how many cultivable microbes bats host on their body surfaces and how much bats contribute to spreading of microbes. A moistened sterile cotton swab was used to swab the body of a bat. The cotton swab was placed into a tube with $4 \mathrm{~mL}$ of physiological saline and thoroughly shaken. Finally, one $\mathrm{mL}$ of the suspension was spread on RIDA ${ }^{\circledR}$ COUNT test plates (Total Aerobic Count, E. coli/Coliform, Yeast\& Mold Rapid). Cultivation conditions were as described above. Microbial counts from the fur coat were expressed as CFU per surface. Two individuals of Rhinolophus ferrumequinum and R. hipposideros were swabbed at the beginning of hibernation (October-November 2010).

\section{Statistical Evaluations}

Canonical correspondence analysis was used to correlate data of abundance of all cultivable microbial groups, E. coli (EC), non-E. coli coliforms (NECCO), non-coliform bacteria (NCOBA), and yeasts and molds (Y\&M) with environmental variables. The NECCO count was calculated as the number of $E$. coli colonies subtracted from the total coliform counts, and the NCOBA count represented all bacteria excluding coliforms (Oarga et al., 2012). Parametric multivariate analysis was run by the program package CANOCO 4.5 (ter Braak and Šmilauer, 2002). The significance of environmental variables in the analysis was tested by a Monte Carlo permutation test. No transformations of the environmental data were applied.

\section{Results AND Discussion}

\section{Bat GuANo}

Animal excrement is an important source of nutrients, including bat guano in caves (Deharveng, 2005). Guano contains diverse microbiota (Chroňaková et al., 2009) and is a source for microbial aerosolization, which represents a potential biohazard for humans and bats, (e.g., Alteras, 1966; Jülg et al., 2008). Fresh guano is basic, and older guano becomes acidic (Moulds, 2006). Based on macroscopic observation and $\mathrm{pH}$ measurements, guano samples were assigned as fresh if they were up to one season old and neutral to alkaline. No correlations were observed between physical guano parameters $(\mathrm{pH}$, volume, surface) and 


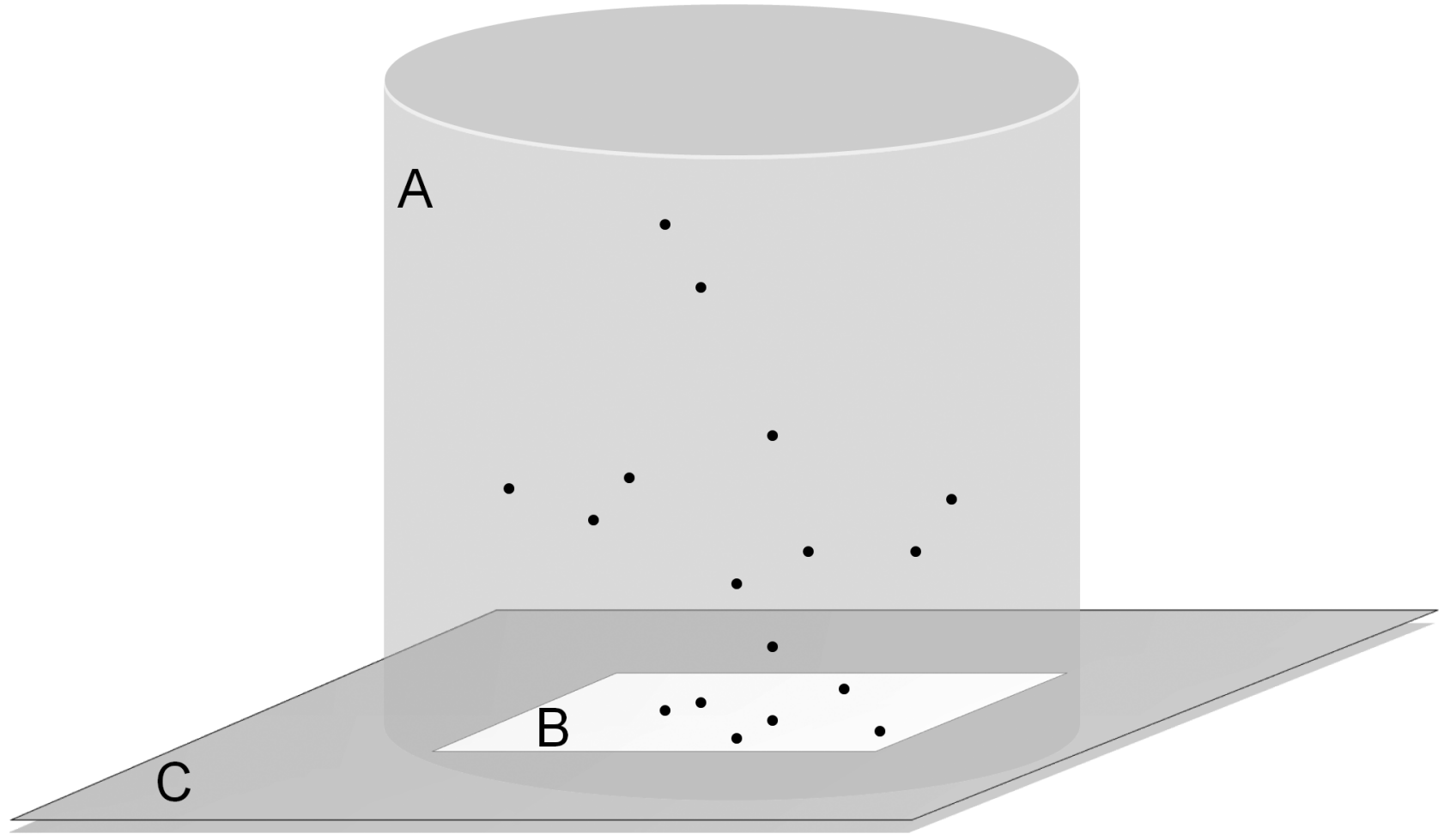

Figure 1. Schematic representation of aerosolization experiment. A, beaker with minute particles represented as dots; B, RIDA ${ }^{\circledR}$ COUNT microbiological medium; C, flexible support with attached microbiological medium.

microbial groups. The biggest guano heap was in Adam Cave (Table 4). The samples of guano varied in concentration of bacteria (up to $1.9 \times 10^{10} \mathrm{CFU} / \mathrm{g}$ ), coliforms (up to $2.2 \times 10^{8} \mathrm{CFU} / \mathrm{g}$ ), E. coli (up to $1.0 \times 10^{8} \mathrm{CFU} / \mathrm{g}$ ), and yeasts and molds (up to $1.7 \times 10^{7} \mathrm{CFU} / \mathrm{g}$ ). The concentrations of fungi varied considerably; interestingly no isolates were retrieved from old guano samples from Gura Dobrogei Cave (Table 5). Coliforms and E. coli were not detected in old and dry guano samples from Gura Dobrogei Cave and Topolniţa Cave. All guano samples positive on E. coli-RIDA ${ }^{\circledR}$ COUNT specific plate were fresh, a few weeks or a few months old. By using the API identification scheme, Chryseomonas luteola (99.9\% ID) and Burkholderia cepacia (99.9\% ID) were identified in fresh guano from Adam Cave, and in addition, B. cepacia was present in old guano from Topolniţa Cave. In a previous study of microbial quantification from guano from Topolniţa Cave, Hodorogea (1972) showed approximately a 150 -fold decrease in number of bacteria in the $10-20 \mathrm{~cm}$ layer compared with the surface layer $(1-5 \mathrm{~cm})$, and fungal concentration was approximately 100-fold higher in the lower layer compared to the guano surface (Hodorogea, 1972).

\section{Atmospheric Conditions in Caves}

The highest temperature differences among sampling sites in the same cave were observed in Meziad Cave during sampling in October $2011\left(6.6{ }^{\circ} \mathrm{C}\right)$, and in Cheile Turzii
Cave in July $2011\left(4.1^{\circ} \mathrm{C}\right.$ ) (for temperature ranges see Table 3). In both caves, even in colder months, slightly higher temperatures were observed in the sectors with the biggest guano heaps. Temperature differences between sampling sites were high in Meziad Cave also during sampling in November $2010,2.7^{\circ} \mathrm{C}$, and in Fuşteica Cave in October 2010, $2.1{ }^{\circ} \mathrm{C}$. In other caves, temperature differences were smaller. The highest air temperatures were measured in Adam Cave $\left(26.0\right.$ to $27.3{ }^{\circ} \mathrm{C}$ ), with a difference of $1.3{ }^{\circ} \mathrm{C}$ between sampling sites. The biggest differences in relative humidity among sites in the same cave were in Meziad Cave in October 2011 at 27.5\% and in November 2010 at $14.4 \%$. The next higher differences among sites were in Fuşteica Cave $(20 \%)$, followed by Cheile Turzii Cave (8.4\%); this cave had also the lowest measured relative humidity ( 42.8 to $51.2 \%$ ). When $\mathrm{CO}_{2}$ concentration was measured, the biggest differences among sampling sites were in Meziad Cave during November 2010 sampling (175 ppm), followed by Răstoci Cave (133 ppm) and Adam Cave (103 ppm). In Adam Cave, the concentration was the highest among all caves, ranging between 1,307 and 1,410 ppm (Table 3).

\section{Airborne Microbes}

Except in Fussteica Cave and Meziad Cave, the total concentration of airborne bacteria was higher than the total concentration of airborne yeast and molds (Fig. 2). In Adam Cave, the concentration of airborne bacteria was the 
D.R. Borda, R.M. Năstase-Bucur, M. Spînu, R. Uricariu, and J. Mulec

Table 3. Ranges of atmospheric parameters during sampling.

\begin{tabular}{lcccc}
\hline Cave & Date $(\mathrm{mm} / \mathrm{dd} / \mathrm{yy})$ & Temperature $\left({ }^{\circ} \mathrm{C}\right)$ & Relative Humidity $(\%)$ & $\mathrm{CO}_{2}(\mathrm{ppm})$ \\
\hline Adam Cave & $10 / 29 / 10$ & $26.0-27.3$ & $96.4-99.8$ & $1307-1410$ \\
Cheile Turzii Cave & $07 / 15 / 11$ & $14.8-18.9$ & $\ldots$ & $\ldots$ \\
& $10 / 16 / 11$ & $8.4-9.3$ & $42.8-51.2$ & $410-470$ \\
Fuşteica Cave & $10 / 28 / 10$ & $8.2-10.3$ & $80.0-100.0$ & $421-423$ \\
Gura Dobrogei Cave & $10 / 23 / 11$ & $11.0-12.8$ & $\ldots$ & $\ldots$ \\
Meziad Cave & $11 / 02 / 10$ & $11.5-14.2$ & $84.3-98.7$ & $397-572$ \\
& $07 / 26 / 11$ & $13.3-14.6$ & $\ldots$ & $\ldots$ \\
Rastoci Cave & $10 / 17 / 11$ & $7.5-14.1$ & $62.9-90.4$ & $370-416$ \\
Topolniţa Cave & $10 / 25 / 10$ & $8.1-8.8$ & $96.0-100.0$ & $418-551$ \\
\hline
\end{tabular}

highest compared to other caves, probably due to the large volume and contact surface of guano (Table 4). High temperature and high humidity $(96.5 \%$ to $99.8 \%)$ in combination with vaporized compounds from guano that can serve as nutrients for microbial multiplication create an excellent air habitat for microbes. In addition, intermittent thermal emanations in this cave can introduce additional compounds into cave atmosphere and enhance the aerosolization effect. The lowest concentration of airborne microbes was in Fuşteica Cave, where guano heaps were located along both sides of the riverbed. The low concentration can be related to the permanent flow of the underground river that constantly washes the central part of the guano deposit and creates continual water saturation of the air, so that aerosol particles settle relatively quickly.

Airborne microorganisms had previously been studied in Romanian caves (Borda and Borda, 2004; Borda et al., 2004) with different ranges of cultivable aerobic bacteria (56 to $1,021 \mathrm{CFU} / \mathrm{m}^{3}$ ) and fungi (52 to $22,373 \mathrm{CFU} / \mathrm{m}^{3}$ ). When caves were rich in guano, total aerobic bacteria of up to $11,317 \mathrm{CFU} / \mathrm{m}^{3}$ were detected. A direct comparison with this study is not appropriate due to the use of different sampling methods and cultivation media; in this study RIDA ${ }^{\circledR}$ COUNT cultivation plates were used and results are reported as CFU/20 $\mathrm{cm}^{2} / 20 \mathrm{~min}$.

Coliform bacteria and E. coli, representative of fecal enterobacteria and common sources of enteric infections (Guentzel, 1996), were screened to observe microbial load that probably originated from feces. Concentrations of airborne coliforms varied reasonably. Typical E. coli colonies on RIDA ${ }^{\circledR}$ COUNT E. coli/Coliform plates were not detected in the air in Adam Cave, Cheile Turzii Cave, and Fuşteica Cave (Fig. 3). Furthermore, despite high concentration of airborne coliforms and total bacteria in Adam Cave and Cheile Turzii Cave, no typical E. coli colonies were retrieved on the media, which indicates that $E$. coli is short-lived when airborne and its presence in the cave air is more or less random. Additionally, the results of in situ aerosolization showed that $E$. coli is hard to find in aerosols (Fig. 6). E. coli does not survive generally more than two or three weeks in low-nutrient environments in a viable and cultivable state (Neidhardt et al., 1996), and indications of its presence in nutrient-poor cave habitats should be carefully examined (Barton and Pace, 2005). Airborne fecal coliforms generally do not survive long outdoors, so the probability of causing infections for wildlife and humans is low (Hughes, 2003). Similar conclusion could be drawn for the underground environment.

Distinct bacterial colonies from Adam Cave and Topolniţa Cave that developed on the RIDA ${ }^{\circledR} \mathrm{COUNT}$ Total Aerobic were identified using API as Klebsiella pneumoniae ssp. ozaenae, Salmonella arizonae, and Salmonella spp. The source of these microbes is very likely bats' intestines (e.g., Adesiyun et al., 2009; Di Bella et al., 2003). These microbes are also present in human intestines (Guentzel, 1996). In the air in Topolniţa Cave, a nonEnterobacteriaceae isolate, Chryseomonas luteola $(99.9 \%$ ID), was also found.

Table 4. Physical characteristics of studied guano heaps in the investigated caves.

\begin{tabular}{lcccc}
\hline Cave & Studied Guano Heaps & $\mathrm{pH}$ & Volume, $^{3}$ & Surface, $^{2}$ \\
\hline Adam Cave & 1 & 4.4 & 32.710 & 43.90 \\
Cheile Turzii Cave & 1 & $5.8-8.5$ & $0.010-0.400$ & $0.25-4.00$ \\
Fuşteica Cave & 3 & $4.0-6.5$ & $0.001-0.058$ & $0.30-1.00$ \\
Gura Dobrogei Cave & 4 & $4.8-7.2$ & $0.001-0.610$ & $0.09-3.51$ \\
Meziad Cave & 2 & $4.7-7.8$ & $0.015-1.360$ & $1.54-6.60$ \\
Răstoci Cave & 1 & 4.5 & 0.049 & 0.98 \\
Topolniţa Cave & 2 & $4.0-6.8$ & $0.375-9.600$ & $3.75-40.00$ \\
\hline
\end{tabular}


Table 5. Microbial counts in guano samples expressed as colony-forming units per gram after 48 hours of incubation for bacteria and 72 hours for yeasts and molds.

\begin{tabular}{lcccc}
\hline Cave & Bacteria $(\mathrm{CFU} / \mathrm{g})$ & Coliforms $(\mathrm{CFU} / \mathrm{g})$ & E.coli $(\mathrm{CFU} / \mathrm{g})$ & Yeast and Molds $(\mathrm{CFU} / \mathrm{g})$ \\
\hline Adam Cave & $2.1 \times 10^{8}-2.1 \times 10^{8}$ & $3.37 \times 10^{5}-6.5 \times 10^{5}$ & $1.4 \times 10^{4}-2.2 \times 10^{5}$ & $2.5 \times 10^{6}-1.7 \times 10^{7}$ \\
CheileTurzii Cave & $6.5 \times 10^{7}-1.9 \times 10^{10}$ & $1.7 \times 10^{6}-2.0 \times 10^{8}$ & $1.2 \times 10^{6}-1.0 \times 10^{8}$ & $5.9 \times 10^{3}-1.7 \times 10^{7}$ \\
Fuşteica Cave & $8.8 \times 10^{4}-1.7 \times 10^{6}$ & $1.8 \times 10^{3}-3.8 \times 10^{4}$ & 0.0 & $1.0 \times 10^{5}-2.3 \times 10^{6}$ \\
Gura Dobrogei Cave & $9.3 \times 10^{3}-7.9 \times 10^{5}$ & $0.0-9.3 \times 10^{4}$ & $0.0-6.1 \times 10^{3}$ & $0.0-3.4 \times 10^{4}$ \\
Meziad Cave & $3.1 \times 10^{5}-2.2 \times 10^{8}$ & $3.9 \times 10^{3}-9.8 \times 10^{7}$ & $0.0-3.1 \times 10^{6}$ & $7.2 \times 10^{1}-3.6 \times 10^{6}$ \\
Răstoci Cave & $1.2 \times 10^{5}$ & $2.2 \times 10^{3}$ & 0.0 & $6.8 \times 10^{4}$ \\
Topolniţa Cave & $3.6 \times 10^{3}-1.1 \times 10^{9}$ & $0.0-2.2 \times 10^{8}$ & $0.0-8.3 \times 10^{4}$ & $9.2 \times 10^{4}-8.9 \times 10^{5}$ \\
\hline
\end{tabular}

Screening for the presence of Streptococcus and Staphylococcus was performed; they are an important part of indoor atmospheres (Mandal and Brandl, 2011; Hospodsky et al., 2012). Staphylococcus is usually used as an indicator for microbiota from skin and mucous membranes (Aydogdu et al., 2005; Schulz et al., 2004), and Streptococcus indicates oral, pharyngeal, and skin bacterial biota and even faecal soil pollution (Kibbey et al., 1978). Except for sampling in Meziad Cave in July 2011, the concentration of Staphylococcus in the air exceeded counts of Streptococcus (Fig. 4). Concentration of staphylococci and streptococci are frequently elevated in the proximity of guano heaps during the summer when bats are active and fly in their underground roosts (Borda et al., 2004). The biochemical profile of two isolates from Adam Cave atmosphere revealed Staphylococcus and Micrococcus (99.8\% ID). Micrococci are not as common as staphylococci; however, both are frequently present in bat guano (Mohod, 2011; Vandžurová et al., 2013). This group of microbes can survive in the air for a long time; for example, Staphylococcus aureus can survive several months on fabric or dust particles (Mitscherlich and Marth, 1984). Under natural cave conditions airborne Staphylococcus and Streptococcus are expected to be viable much longer than E. coli.

In caves with bat guano, elevated concentrations of airborne bacteria, and to a lesser extent, fungi were detected in our study. We identified Chryseomonas luteola, E. coli, Klebsiella pneumoniae ssp. ozaenae, Micrococcus, Salmonella, Staphylococcus, and Streptococcus, as well as unidentified cultivable bacteria, coliforms, and enterobacteria. All these microbes can be indicative for bats and guano, and in caves, they might represent a biohazard because they can survive longer as airborne there than in other organic-rich environments with more environmental stressors. High microbial concentrations in guano did not always correspond to high concentration of airborne microbes at the same guano heap (compare Fig. 2 and Table 5).

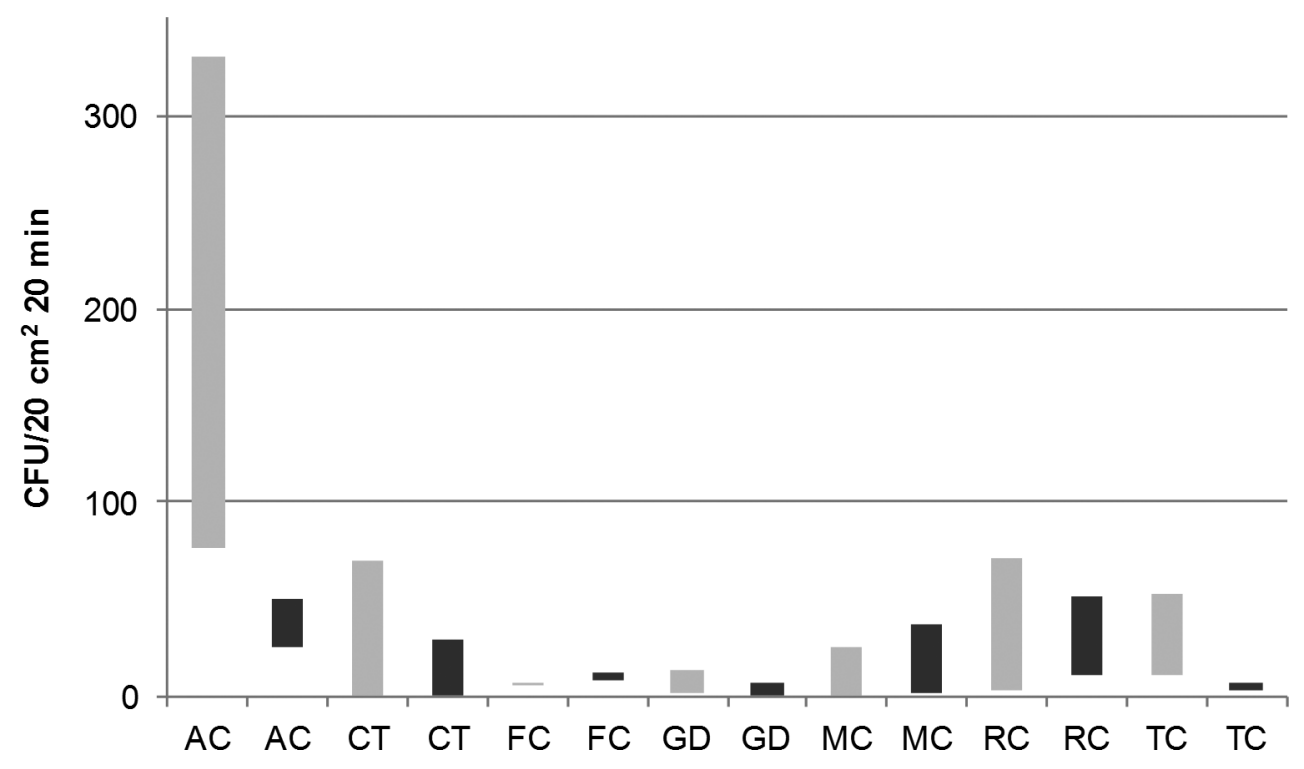

Figure 2. Ranges of concentrations of airborne microbes (grey, total bacteria; black, yeasts and molds) in the air of Adam Cave (AC), Fuşteica Cave (FC), Meziad Cave (MC), Răstoci Cave (RC), and Topolnița Cave (TC) in autumn of 2010, and in Cheile Turzii Cave (CT), Gura Dobrogei Cave (GD), and Meziad Cave (MC) in autumn of 2011. 


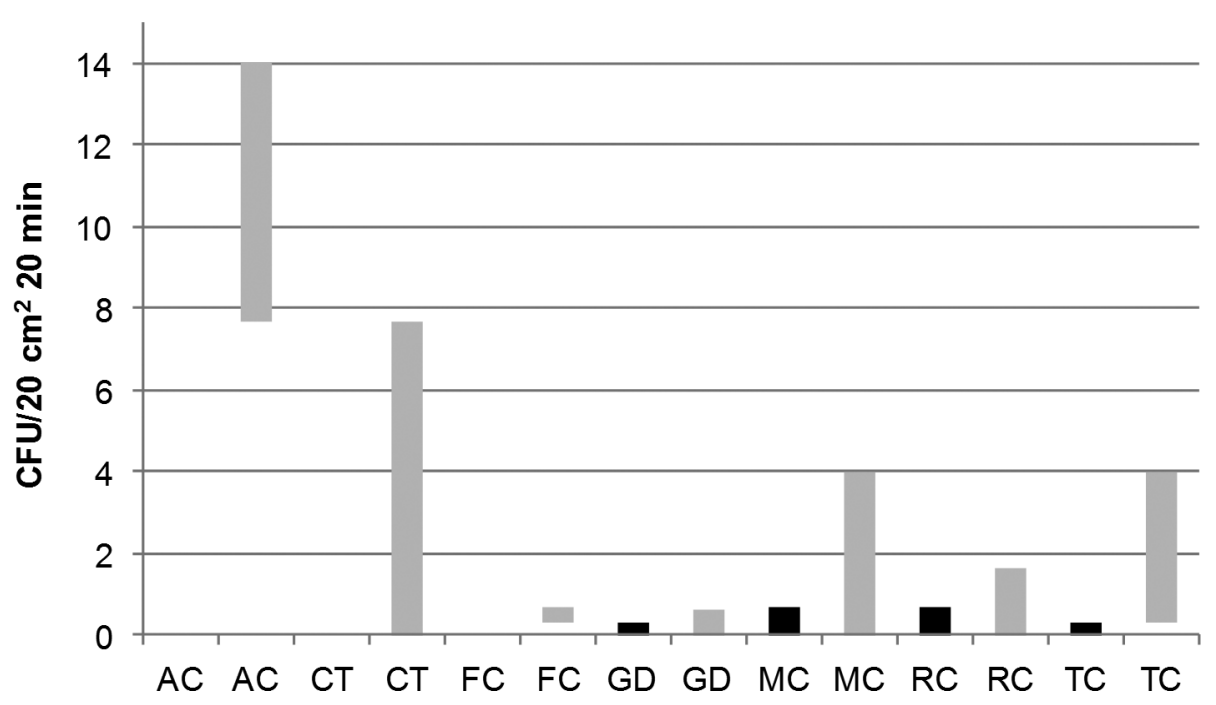

Figure 3. Ranges of concentrations of coliforms (grey) and $E$. coli (black) in the air of Adam Cave (AC), Fuşteica Cave (FC), Meziad Cave (MC), Răstoci Cave (RC), and Topolnița Cave (TC) in autumn of 2010, and in Cheile Turzii Cave (CT), Gura Dobrogei cave (GD), and Meziad Cave (MC) in autumn of 2011.

\section{Airborne Microbes and Atmospheric Parameters}

Canonical correspondence analysis was performed on the basis of six variables, if available: temperature, relative humidity, air pressure, $\mathrm{CO}_{2}$, distance to the cave entrance from each individual sampling site, and distance to the guano heap from each individual sampling site. Only a small portion of measured environmental variables explained the variances (Table 6). Measured physical parameters explained the highest variance in the structure of microbial communities in the autumn in Gura Dobrogei Cave (October 2011) by 0.31 and in Meziad Cave (November 2011) by 0.12 . In other caves in autumn and also in summer they explained less than 0.09. Temperature had a significant impact $(\mathrm{p}<0.05)$ on the bioaerosol abundance in Meziad Cave in November 2011 and RH in Topolniţa Cave in October 2010.

In a study from Postojna Cave, Slovenia, (Mulec et al., 2012c) where the impacting sampling method was used, in the transition periods, i.e., spring and autumn, physical parameters explained variances less (winter 0.62, spring 0.25 , summer 0.49 , autumn 0.08 ). The sampling method used in this study is based on gravity settling and is not directly comparable. The method based on settling is very sensitive to any air disturbances that can cause the particles to deviate from their vertical settling route. Other factors that influence settling behavior, in addition to air movements, pressure, temperature, and human and animal movements, are characteristics of an individual particle,

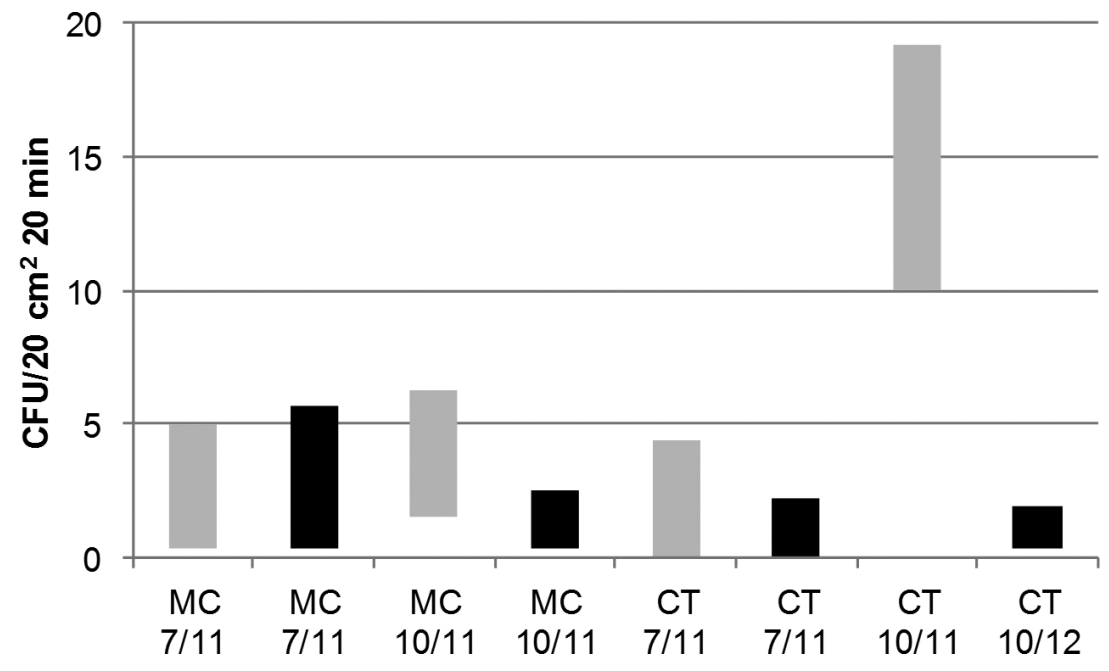

Figure 4. Ranges of concentrations of airborne Staphylococcus (grey) and Streptococcus (black) in Meziad Cave (MC) and Cheile Turzii Cave (CT) in July (7) and October (10) of 2011. 
Table 6. Summary of canonical correspondence analysis analysis using forward selection for explanation of variance by selected variable. Dist_Ent, distance from the closest cave entrance; Dist_Gua, distance to the closest guano heap. AC, Adam Cave; CT, Cheile Turzii Cave; FC, Fuşteica Cave; GD, Gura Dobrogei Cave; MC, Meziad Cave; RC, Rãstoci Cave; TC, Topolniţa Cave. In bold, $p<0.05$.

\begin{tabular}{|c|c|c|c|c|c|c|c|c|c|c|}
\hline \multirow[b]{2}{*}{ Parameter } & \multicolumn{10}{|c|}{ Cave / Period } \\
\hline & $\begin{array}{l}\mathrm{AC} / \\
\text { Oct } 10\end{array}$ & $\begin{array}{l}\text { CT / } \\
\text { Jul } 11\end{array}$ & $\begin{array}{l}\text { CT / } \\
\text { Oct } 11\end{array}$ & $\begin{array}{l}\text { FC / } \\
\text { Oct } 10\end{array}$ & $\begin{array}{l}\text { GD / } \\
\text { Oct } 11\end{array}$ & $\begin{array}{c}\mathrm{MC} / \\
\text { Nov } 10\end{array}$ & $\begin{array}{l}\mathrm{MC} / \\
\text { Oct } 11\end{array}$ & $\begin{array}{l}\text { MC / } \\
\text { Oct } 11\end{array}$ & $\begin{array}{l}\mathrm{RC} / \\
\text { Oct } 10\end{array}$ & $\begin{array}{l}\text { TC / } \\
\text { Oct } 10\end{array}$ \\
\hline \multicolumn{11}{|l|}{ Temperature } \\
\hline$p$ & 1.00 & 1.00 & & 1.00 & 0.24 & 0.05 & 1.00 & 0.14 & 1.00 & 1.00 \\
\hline var. & 0.08 & 0.02 & & 0.01 & 0.02 & 0.10 & 0.02 & 0.05 & 0.01 & 0.00 \\
\hline \multicolumn{11}{|l|}{ Relative Humidity } \\
\hline$p$ & & & & & & 1.00 & & 1.00 & & 0.03 \\
\hline var. & & & & & & 0.01 & & 0.00 & & 0.06 \\
\hline \multicolumn{11}{|l|}{ Pressure } \\
\hline$p$ & & & 0.171 & & & & & 0.43 & 0.37 & \\
\hline var. & & & 0.05 & & & & & 0.02 & 0.03 & \\
\hline \multicolumn{11}{|l|}{$\mathrm{CO}_{2}$} \\
\hline$p$ & & & & & & & & & 0.38 & 0.12 \\
\hline var. & & & & & & & & & 0.02 & 0.00 \\
\hline \multicolumn{11}{|l|}{ Dist_Ent } \\
\hline$p$ & & & & & & & 0.22 & & & 0.36 \\
\hline var. & & & & & & & 0.05 & & & 0.03 \\
\hline \multicolumn{11}{|l|}{ Dist_Gua } \\
\hline$p$ & & 0.35 & & & 0.09 & 0.20 & 0.43 & & & \\
\hline var. & & 0.02 & & & 0.29 & 0.01 & 0.01 & & & \\
\hline Variance explained & 0.09 & 0.04 & 0.05 & 0.01 & 0.31 & 0.12 & 0.08 & 0.07 & 0.06 & 0.09 \\
\hline Sum of all eigen values & 0.08 & 0.05 & 0.05 & 0.01 & 0.31 & 0.12 & 0.08 & 0.07 & 0.06 & 0.09 \\
\hline
\end{tabular}

such as its size and mass, and morphological characteristics of a space that, for example, enables creating of air gaps. Interestingly, distances from guano did not always contribute to the common variance during autumn samplings, but during both summer samplings in Cheile Turzii Cave and in Meziad Cave they did. This can be attributed as a seasonal effect connected with the presence of bats and very fresh guano droppings and its aerosolization. In that period, a pronounced gradient of airborne microbes can be formed radiating from a site of a bat colony and its guano heap, but more data are needed to confirm that. Nevertheless, conditions in cave atmospheres are complex and dynamic and become more complicated when other factors are involved, such as aerosolized microbes/particles from animal excrements. Sampling position in the space has also very important influence on the detection of bioaerosol signals.

\section{Vertical Microbial Gradient and Effect of Seasonality}

Concentration of airborne microorganisms at different heights above the ground varied, indicating that selection of bioaerosols sampling positions is important and should be clearly reported (Fig. 5). The concentration of airborne microorganisms was generally higher when bioaerosols were sampled at the ground level, in Cheile Turzii Cave on average 3.4 orders of magnitude and in Meziad Cave on average 1.3 orders. In both Cheile Turzii Cave and Meziad Cave, the total microbial counts were higher in summer than in autumn. Total microbial counts were defined as a sum of counts of E. coli (EC), non-E. coli coliforms (NECCO), non-coliform bacteria (NCOBA), and yeasts and molds (Y\&M) (Fig. 5). Coliform bacteria other than $E$. coli were detected in both caves in the summer period. In addition, in Meziad Cave E. coli was detected airborne on $E$. coli-specific plates, while in Cheile Turzii Cave these bacteria were not observed in the air at all. Sampling site MC2 in Meziad Cave is located in a big chamber (Pyramid Room, approx. 220,000 $\mathrm{m}^{3}$ ) with $0.015 \mathrm{~m}^{3}$ of guano, and sampling site MC3 is located in a smaller chamber (Bat Room, approx. $37,500 \mathrm{~m}^{3}$ ) with a greater quantity of guano $\left(\sim 1.36 \mathrm{~m}^{3}\right)$ that is more scattered in the space. The Bat Room, which had a higher concentration of airborne microbes, shelters from May to August a big nursery colony of about five to seven thousand individuals of Myotis myotis/M. oxygnathus mixed with Miniopterus schreibersii. 
D.R. Borda, R.M. NĂstase-Bucur, M. Spînu, R. Uricariu, and J. Mulec

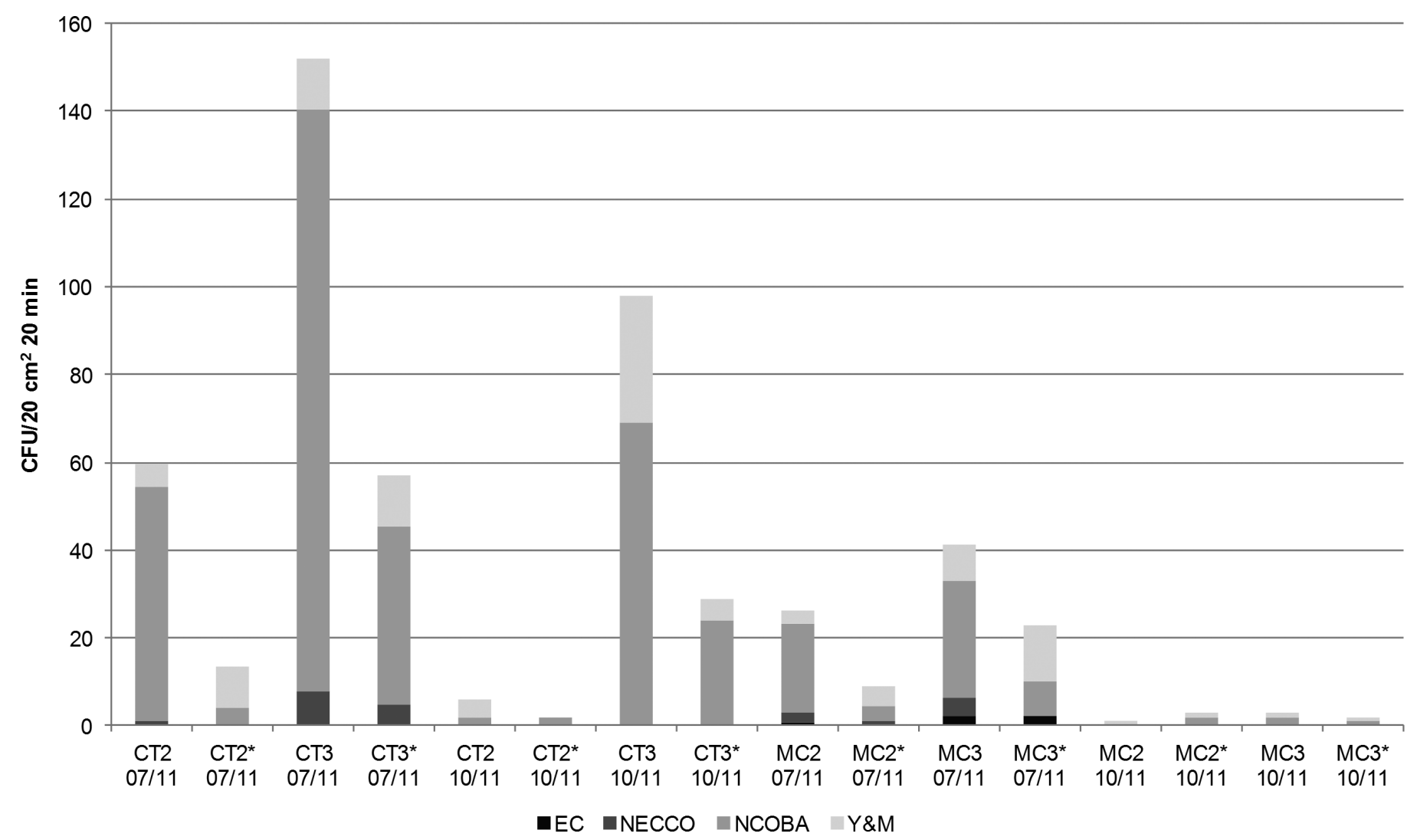

Figure 5. Effect of season and sampling position on concentration of airborne microbes at Cheile Turzii Cave (CT) sampling sites 2 and 3 and at Meziad Cave (MC) sample sites 2 and 3. Sampling was performed in July (7) and October (10) 2011. Samples taken 1.5 meters above the ground are designated by an asterisk; other samples were taken at ground level. EC, $E$. coli; NECCO, other coliforms; NCOBA, non-coliform bacteria; Y\&M, yeasts and molds.

The proportion of microbial subgroups seems to be the same at each tested site, with generally smaller concentrations in the autumn when air changes with the subsurface are suppressed and maternity colonies of bats are dispersed. The concentrations of airborne fungi were rather low compared to bacteria (Fig. 5). It is important to underline that sampling at $1.5 \mathrm{~m}$ above the ground was chosen as the level of human breathing to point out the possibility of getting in contact with bioaerosols.

\section{Aerosolization of Microbes from Guano}

Percentage of aerosolized microbial groups from samples from Cheile Turzii Cave, Gura Dobrogei Cave, and Meziad Cave are summarized in Figure 6. Total bacterial counts ranged from 0.00 to $0.10 \%$, coliforms from 0.00 to $0.16 \%$, E. coli $0.00 \%$, enterobacteria from 0.00 to $0.03 \%$, and yeasts and molds from 0.00 to $3.35 \%$. In the three independent sampling campaigns, aerosolization of $E$. coli was unsuccessful, although concentration of this microbe in different tested guanos varied from 0.0 to $1.7 \times 10^{7}$ $\mathrm{CFU} / \mathrm{g}$ (Table 5). On the other hand, successful aerosolization of coliform bacteria and enterobacteria indicated that aerosolization of $E$. coli may be possible. Transmission of $E$. coli via cave air is probably quite limited.
Artificially induced aerosolization resulted in a large amount of aerosolized fungi from guano. Aerosolization of microbes in caves can be easily enhanced by disturbing guano surfaces while walking. From other microbes-rich materials in different environments, aerosolization can also be caused by wind and animals. Due to their small size, microbes can persist long in the air. For example, droplets more than $5 \mu \mathrm{m}$ in diameter sediment more quickly on the ground than droplets that are less than $5 \mu \mathrm{m}$, which can remain suspended in the air for a long time (D'arcy et al., 2012). As bat guano in Topolniţa Cave was already reported to be the source of $H$. capsulatum (Alteras, 1966), the estimation that more than $3 \%$ of cultivable fungi may be aerosolized gives an important warning to avoid contact with potential fungal pathogens from guano. High aerosolization potential of fungal spores from guano can be the answer for many cases of guano-associated histoplasmoses reported in landfill, bridge, and wagon-train workers (Gustafson et al., 1981; Huhn et al., 2005), during home renovations (Schoenberger et al., 1988), or among cavers (Ashford et al., 1999).

\section{Bats as Vectors for Microorganisms}

Bats were swabbed to get an estimation on transmission of microbes on their bodies. Swabbing of Rhinolophus 


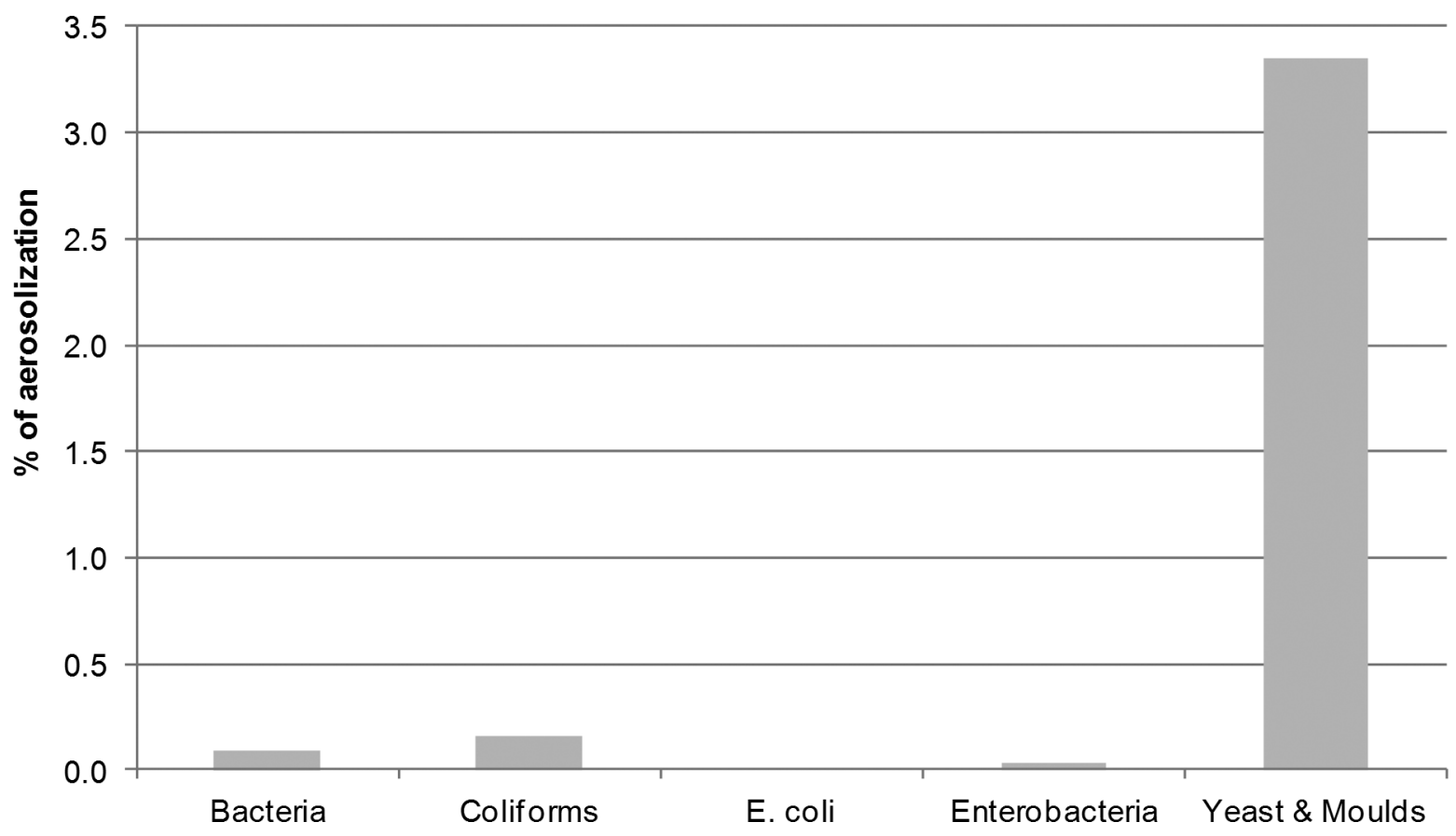

Figure 6. Percentage of aerosolised microbial groups from bat guano.

ferrumequinum coats produced higher numbers of microorganisms than $R$. hipposideros coats (Table 7). Although their body sizes are quite different, $R$. ferrumequinum being almost twice that of $R$. hipposideros $(57$ to $71 \mathrm{~mm}$ versus 37 to $45 \mathrm{~mm}$ head and body; 350 to $400 \mathrm{~mm}$ versus 192 to $254 \mathrm{~mm}$ wingspan), it is possible that behavior is more important for microbial contamination of cave air. In the sampling period at the beginning of November, individuals of $R$. hipposideros were already prepared to hibernate and their daily torpor was already very deep, in contrast to $R$. ferrumequinum, which were still active. Social behavior of bats could also play an important role in spreading of microorganisms; solitary bats rarely get in contact with other bats. $R$. hipposideros usually hang free as isolated individuals and during hibernation wrap themselves completely in their wings, but individuals of $R$. ferrumequinum hibernate in big clusters, where bats coats get in contact because of incomplete wing wrapping. The role of bat species in the propagation and spread of fungi is already known. On one hand their feces serve as a source of nutrients for microbes, and on the other hand they can be active disseminators of fungi in the environment (Hoff and Bigler, 1981).

\section{Conclusions}

Elevated concentrations of bacteria, including those of enteric origin and to a lesser extent of fungi, were detected in, and around, bat guano. Favorable atmospheric conditions for microbial multiplication, such as high temperature and vaporized compounds from organic matter, produced the highest counts of airborne microorganisms. A cave rich with guano, with high relative humidity, and with a flowing river had the lowest concentrations of airborne microbes. Concentrations of airborne microorganisms were higher at ground level compared to the concentrations at $1.5 \mathrm{~m}$ above the ground. Coliform bacteria were frequently detected in air in areas with high organic matter and animal excrements. E. coli was rarely found in air, and its successful aerosolization

Table 7. Swab analyses of fur coat of Rhinolophus from Meziad Cave expressed as CFU/20 $\mathrm{cm}^{2}$ after 48 hours of plate incubation for bacteria and 72 hours for yeast and molds.

\begin{tabular}{lcccc}
\hline Bat Species & $\begin{array}{c}\text { Total Bacteria } \\
\left(\mathrm{CFU} / 20 \mathrm{~cm}^{2}\right)\end{array}$ & $\begin{array}{c}\text { E.coli } \\
\left(\mathrm{CFU} / 20 \mathrm{~cm}^{2}\right)\end{array}$ & $\begin{array}{c}\text { Coliforms } \\
\left(\mathrm{CFU} / 20 \mathrm{~cm}^{2}\right)\end{array}$ & $\begin{array}{c}\text { Yeast and Molds } \\
\left(\mathrm{CFU} / 20 \mathrm{~cm}^{2}\right)\end{array}$ \\
\hline R. ferrumequinum 1 & 821 & 0 & 0 & 1067 \\
R. ferrumequinum 2 & 2005 & 0 & 135 & 1030 \\
R. hipposideros 1 & 0 & 0 & 0 & 21 \\
R. hipposideros 2 & 5 & 0 & 0 & 7 \\
\hline
\end{tabular}


was not achieved. Microbial aerosolization rate from guano was for bacteria up to $0.10 \%$, and for fungi up to $3.35 \%$. Staphylococcus and Streptococcus were found in air close to bat guano. In the summer, microbial load in the cave air was elevated, which we attribute to the presence of bats. The proportion of microbial groups was preserved in the summer and autumn periods. Bats and especially their social behavior are crucial for introduction and spread of airborne microbes. Airborne microbes indicative of bats and guano and especially a high potential of fungal aerosolization represent a biohazard for animals and humans in caves. Activities that lead to aerosol formation from animal excrements should be avoided. In comparison to other external environments, caves provide a simplified system of studying bioaerosols, although even in caves complex relationships between atmospheric and microbiological parameters co-exist.

\section{ACKNOWLEDGEMENTS}

The study was supported by the Research Programme P6-0119 "Karst Research" and PNII-M III (BI-RO/10-11012) Research Bilateral Project between Slovenia and Romania. Authors are grateful to Anca Dragu for her help during field and lab work, and also to Andreea Oarga for assisting during field work. We thank Sorin Sosu, who facilitated the access in Topolniţa Cave, and to Emilia Liddell for language assistance.

\section{REFERENCES}

Adesiyun, A.A., Stewart-Johnson, A., and Thompson, N.N., 2009, Isolation of enteric pathogens from bats in Trinidad: Journal of Wildlife Diseases, v. 45, no. 4, p. 952-961. doi:10.7589/0090-3558-45.4.952.

Alteras, I., 1966, First Romanian isolation of Histoplasma capsulatum from the soil: International Journal of Dermatology, v. 5, no. 2, p. 69-71. doi:10.1111/j.1365-4362.1966.tb05188.x.

ANPM, 2013, Agenţia naţională pentru protecţia mediului: Harta delimitării regiunilor geografice (map of Romanian geographic regions), http://www.anpm.ro/upload/12561_Anexa2_harta_regbiogeografice. pdf [accessed May 15, 2013].

Ashford, D.A., Hajjeh, R.A., Kelley, M.F., Kaufman, L., Hutwagner, L., and McNeil, M.M., 1999, Outbreak of histoplasmosis among cavers attending the National Speleological Society Annual Convention, Texas, 1994: The American Journal of Tropical Medicine and Hygiene, v. 60, no. 6, p. 899-903.

Aydogdu, H., Asan, A., Otkun, M.T., and Ture, M., 2005, Monitoring of fungi and bacteria in the indoor air of primary schools in Edirne City, Turkey: Indoor and Built Environment, v. 14, p. 411-425. doi:10. 1177/1420326X05057539.

Bandrabur, G., and Radu, R., 1994, Recherches hydrogéologiques dans la zone de Tureni-Petreştii de Sus (Roumanie). Utilisation de l'électrométrie en hydrogéologie: Theoretical and Applied Karstology, no. 7, p. 109-114.

Barton, H.A., and Pace, N.R., 2005, Discussion: persistent coliform contamination in Lechuguilla cave pools: Journal of Cave and Karst Studies, v. 67 , no. 1 , p. 55-57.

Beldean, P.-V., 2005, Ecological Studies on the Coreoidea (Heteroptera, Insecta) in the Nature Reserve Cheile Turzii (Cluj County): Studia Universitatis Babeş-Bolyai, Studia Biologia, v. 50, no. 1, p. 3-10.

Bleahu, M., Decu, V., Negrea, Ş., Pleşa, C., Povară, I., and Viehmann, I., 1976, Peşteri din România: Bucureşti, România, Editura Ştiinţifică şi Enciclopedică, 415 p.
Borda, C., and Borda, D., 2004, Airborne microorganisms in show caves from Romania: Travaux de L' Institut de Spéologie 'Émile Racoviza", v. 43-44, p. 65-74.

Borda, C., Popescu, S., and El Mahdy, I.C., 2012, Seasonal evolution of the microclimate factors level in a zoo: Bulletin of University of Agricultural Sciences and Veterinary Medicine Cluj-Napoca, Veterinary Medicine, v. 69, no. 1-2, p. 49-53.

Borda, D., 2002a, Chiropterele, in Racoviţă, G., Moldovan, O., and Onac, B.P., eds., Monografia carstului din Munţii Pădurea Craiului: ClujNapoca, Presa Universitară, p. 172-182.

Borda, D., 2002b, The distribution of bats in Romanian caves (I): Travaux de L' Institut de Spéologie "Émile Racoviza", v. 37-38, p. 223-230.

Borda, D., Borda, C., and Tămaş, T., 2004, Bats, climate and air microorganisms in a Romanian cave: Mammalia, v. 68 , no. 4, p. $337-$ 343. doi:10.1515/mamm.2004.033.

Borda, D., Năstase-Bucur, R., Borda, C., and Gorban, I., 2009, The assessment of the airborne microorganismes in subterranean environment-preliminary data: Bulletin of University of Agricultural Sciences and Veterinary Medicine Cluj-Napoca, Veterinary Medicine, v. 66 , no. 1 , p. $236-242$.

Burghele-Bălăcescu, A., and Avram, S., 1966, Peşteri cercetate în Oltenia, între valea Motrului şi Valea Tismanei: Travaux de L' Institut de Spéologie "Émile Racoviza”, v. 5, p. 21-42.

Carbonnel, J.-P., Decu, V., Olive, P., Povara, I., and Gheorghiu, V., 1996, Premiére datation par C14 du remplissage de guano d'une grotte des Carpates Meridionales: Peştera lui Adam (Roumanie) : Travaux de L' Institut de Spéologie "Émile Racoviza", v. 35, p. 145-154.

Chapman, G.H., 1945, Determination of the Chromogenic Property of Staphylococci: Journal of Bacteriology, v. 50, no. 2, p. 201-203.

Chroňáková, A., Horák, A., Elhottová, D., and Krištůfek, V., 2009, Diverse archaeal community of a bat guano pile in Domica Cave (Slovak Karst, Slovakia): Folia Microbiologica, v. 54, p. 436-446. doi:10.1007/s12223-009-0061-2.

Coroiu, I., David, A., and Borda, D., 2007, Bats hibernacula in Meziad Cave: Miscellanea Chiropterologica, v. 1, p. 77-81.

Costache, I., 2011, Flora şi vegetaţia bazinului Hidrografic inferior al râului Motru, v. I. Flora: Craiova, Romania, Ed. Universitară, 215 p.

D'Arcy, N., Canales, M., Spratt, D.A., and Lai, Ka Man, 2012, Healthy schools: standardisation of culturing methods for seeking airborne pathogens in bioaerosols emitted from human sources: Aerobiologia, v. 28 , no. 4 , p. 413-422. doi:10.1007/s10453-012-9251-5.

Deharveng, L., 2005, Diversity patterns in the tropics, in Culver, D.C., and White, W.B., eds., Encyclopedia of Caves: Burlington, Massachusetts, Elsevier/Academic Press, p. 166-170.

Di Bella, C., Piraino, C., Caracappa, S., Fornasari, L., Violani, C., and Zava, B., 2003, Enteric microflora in Italian chiroptera: Journal of Mountain Ecology, no. 7 (Suppl.), p. 221-224.

Drăghici, C., Popescu, S., Borda, C., and Kallay, Z., 2002, Density and quality of air micro-organisms in poultry houses for broiler chicken: Buletinul Universităţii de Ştiinţe Agricole şi Medicină Veterinară ClujNapoca, Seria Medicină Veterinară, v. 57-58, p. 555-560.

Fabian, M.P., Miller, S.L., Reponen, T., and Hernandez, M.T., 2005, Ambient bioaerosol indices for indoor air quality assessments of flood reclamation: Aerosol Science, v. 36, p. 763-783. doi:10.1016/j.jaerosci. 2004.11.018.

Guentzel, M.N., 1996, Escherichia, Klebsiella, Enterobacter, Serratia, Citrobacter, and Proteus, in Baron, S., ed., Medical Microbiology, 4th edition: University of Texas Medical Branch at Galveston; Chapter 26, http://www.ncbi.nlm.nih.gov/books/NBK8035/, [accessed May 15, 2013].

Gustafson, T.L., Kaufman, L., Weeks, R., Ajello, L., Hutcheson, R.H., Wiener, S.L., Lambe, D.W., Sayvetz, T.A., and Schaffner, W., 1981, Outbreak of acute pulmonary histoplasmosis in members of a wagon train: American Journal of Medicine, v. 71, p. 759-765.

Hodorogea, P., 1972, Recherches microbiologiques dans la grotte de Topolniţa (Roumanie). Premiére note: Travaux de L' Institut de Spéologie "Émile Racoviza", v. 11, p. 335-342.

Hoff, G.L., and Bigler, W.J., 1981, The role of bats in the propagation and spread of histoplasmosis: A review: Journal of Wildlife Diseases, v. 17, no. 2, p. 191-196.

Holmes, M.C., and Lermit, A., 1955, Transport and enrichment media in the isolation of haemolytic streptococci from the upper respiratory tract: Monthly Bulletin of the Ministry of Health and the Public Health Laboratory Service, v. 14, p. 97-103. 
Hospodsky, D., Qian, J., Nazaroff, W.W., Yamamoto, N., Bibby, K., Rismani-Yazid, H., and Peccia, J., 2012, Human occupancy as a source of indoor airborne bacteria: PLoS ONE, v. 7, no. 4, e34867. http://www.plosone.org/article/info\%3Adoi $\% 2$ F $10.1371 \% 2$ Fjournal.pone. 0034867, [accessed May 15, 2013]. doi:10.1371/journal.pone.0034867.

Hughes, K.A., 2003, Influence of seasonal environmental variables on the distribution of presumptive fecal Coliforms around an Antarctic research station: Applied and Environmental Microbiology, v. 69, no. 8, p. 4884-4891. doi:10.1128/AEM.69.8.4884-4891.2003.

Huhn, G.D., Austin, C., Carr, M., Heyer, D., Boudreau, P., Gilbert, G., Eimen, T., Lindsey, M.D., Cali, S., Conover, C.S., and Dworkin, M.S., 2005, Two outbreaks of occupationally acquired histoplasmosis: more than workers at risk: Environmental Health Perspectives, v. 113, no. 5, p. 585-589. doi:10.1289/ehp.7484.

Jülg, B., Elias, J., Zahn, A., Köppen, S., Becker-Gaab, C., and Bogner, J., 2008, Bat-associated histoplasmosis can be transmitted at entrances of bat caves and not only inside the caves: Journal of Travel Medicine, v. 15, p. 133-136. doi:10.1111/j.1708-8305.2008.00193.x.

Kibbey, H.J., Hagedorn, C., and McCoy, E.L., 1978, Use of fecal streptococci as indicators of pollution in soil: Applied and Environmental Microbiology, v. 35, no. 4, p. 711-717.

Lungu, M., 2008, Resurse şi riscuri climaticed in Dobrogea [PhD Thesis]: Universitatea Bucureşti, $279 \mathrm{p}$.

Mandal, J., and Brandl, H., 2011, Bioaerosols in indoor environment - a review with special reference to residential and occupational locations, The Open Environmental and Biological Monitoring Journal, v. 4, p. 83-96. doi:10.2174/1875040001104010083.

Mitscherlich, E., and Marth, E.H., 1984, Microbial Survival in the Environment-Bacteria and Rickettsiae Important in Human and Animal Health: Berlin, Springer-Verlag, 802 p. doi:10.1007/978-3-64269974-0.

Mohod, R.S., 2011, Studies on thermostable alkaliphilic extracellular lipase producing halo-alkaliphilic bacteria from bat guano of Lonar Lake: International Journal of Advance Pharmaceutical and Biological Sciences, v. 1, no. 1, p. 24-29.

Moulds, T.A., 2006, The seasonality, diversity and ecology of cavernicolous guano dependent arthropod ecosystems in southern Australia. [PhD. Thesis]: Adelaide, Australia, The University of Adelaide, $260 \mathrm{p}$. http://hdl.handle.net/2440/37815 [accessed May 15, 2013].

Moza, A.C., 2008, Aspects regarding the mean annual quantities of rainfall in the Crişul Repede hydrographic basin: Analele Universităţii din Oradea, Seria Geografie, v. 18, p. 74-80.

Mulec, J., 2008, Microorganisms in hypogeon: examples from Slovenian karst caves: Acta Carsologica, v. 37, no. 1, p. 153-160.

Mulec, J., Krištůfek, V., and Chroňáková, A., 2012a, Comparative microbial sampling from eutrophic caves in Slovenia and Slovakia using RIDA ${ }^{\circledR}$ COUNT test kits: International Journal of Speleology, v. 41 , no. 1 , p. $1-8$. doi:10.5038/1827-806X.41.1.1.

Mulec, J., Krištůfek, V., and Chroňáková, A., 2012b, Monitoring of microbial indicator groups in caves through the use of RIDA ${ }^{\circledR}$ COUNT kits: Acta Carsologica, v. 41, no. 2-3, p. 287-296.

Mulec, J., Vaupotič, J., and Walochnik, J., 2012c, Prokaryotic and eukaryotic airborne microorganisms as tracers of microclimatic changes in the underground (Postojna Cave, Slovenia): Microbial Ecology, 2012, v. 64, no. 3, p. 654-667. doi:10.1007/s00248-012-0059-1.

Munteanu, C., 2011, Bãile Herculane Resort: Balneo-Research Journal, English Edition, v. 2, no. 3, p. 17-23. doi:10.12680/balneo.2011.1020.

Neidhardt, F.C., Curtis, III, R., Ingraham, J.L., Lin, E.C.C., Low, K.B., Magasanik, B., Reznikoff, W.S., Riley, M., Schaechter, M., and
Umbarger, H.E., 1996, Escherichia coli and Salmonella, Cellular and Molecular Biology: Washington, D.C., American Society for Microbiology Press, $2822 \mathrm{p}$.

Oarga, A., Griessler Bulc, T., Jenssen, P.D., and Mulec, J., 2012, Monitoring of microbial indicator groups in organically heavily loaded wastewater treatment systems by using RIDA ${ }^{\circledR}$ COUNT kits: Fresenius Environmental Bulletin, v. 21, no. 12a, p. 3886-3893.

Pocora, I., and Pocora, V., 2011, Bat communities in four dobrogean caves (Romania): Analele Ştiințifice ale Universităţii ”Alexandru Ioan Cuza" din Iaşi, Biologie animală, v. 57, p. 107-124.

Poulson, T.L., and Lavoie, K.H., 2000, The trophic basis of subsurface ecosystems, in Wilkins, H., Culver, D.C., and Humphreys, W.F., eds., Subterranean Ecosystems: Amsterdam, Elsevier Press, Ecosystems of the World 30, p. 231-249.

Povară, I., Diaconu, G., and Goran, C., 1972, Observations préliminaries sur les grottes influences par les eaux thermo-minérales de la zone Băile Herculane: Travaux de L' Institut de Spéologie "Émile Racoviza", v. 11, p. 355-366.

Robu, M., 2009, Groundwater vulnerability assessment in the Motru Sec karst area, Mehedinţi Mountains: Travaux de L' Institut de Spéologie "Émile Racoviza", v. 48, p. 69-81.

Schoenberger, C.I., Weiner, J.H., Mayo, F.J., Spellman, J., and Waltersdorff, R.G., 1988, Acute pulmonary histoplasmosis outbreak following home renovation: Maryland Medical Journal, v. 37, no. 6, p. $457-460$.

Schulz, J., Hartung, J., Seedorf, J., and Formosa, L.C., 2004, Staphylococci as an indicator for bacterial emissions from a broiler house, in Madec, F., and Clement, G., eds., Proceeedings of In Between Congress of The International Society for Animal Hygiene, Animal production in Europe: The way forward in a changing world, SantMaolo, France, Oct. 2004, v. 1, p. 75-78.

Simon, K.S., 2012, Cave ecosystems, in White, W.B., and Culver, D.C., eds., Encyclopedia of Caves, 2nd ed.: Amsterdam, Academic Press, p. $99-102$.

Sorocovschi, V., and Vodă, M., 2009, The study of drought phenomena in the Transylvania plain using the analysis of the non-periodical variations of precipitations, in Proceedings of the $4^{\text {th }}$ IASME/WSEAS International Conference on Water, Resources, Hydraulics and Hydrology (WHH'09), Cambridge, UK, Feb. 2009: WSEAS Press, p. $163-167$.

ter Braak, C.J.F., and Šmilauer, P., 2002, CANOCO Reference Manual and CanoDraw for Windows User's Guide: Software for Canonical Community Ordination (version 4.5). Ithaca, NY, USA (www. canoco.com): Ithaca, New York, Microcomputer Power, 500 p.

Todoran, V., and Onac, B., 1987, La morphologie de l'exo- et de l'endokarst du plateau de Purcăreţ-Mesteacăn (Plateau du Someş): Theoretical and Applied Karstology, v. 3, p. 127-131.

Vandžurová, A., Bačkor, P., Javorský, P., and Pristaš, P., 2013, Staphylococcus nepalensis in the guano of bats (Mammalia): Veterinary Microbiology, v. 164, no. 1-2, p. 116-121. doi:10.1016/ j.vetmic.2013.01.043.

White, W.B., and Culver, D.C., 2012, Cave, Definition of, in White, W.B., and Culver, D.C., eds., Encyclopedia of Caves, 2nd ed.: Amsterdam: Academic Press, p. 103-107.

Womack, A.M., Bohannan, B.J.M., and Green, J.L., 2010, Biodiversity and biogeography of the atmosphere: Philosophical Transactions of the Royal Society B, Biological Sciences, v. 365, p. 3645-3653. doi:10.1098/rstb.2010.0283. 